\title{
Sakubitril/valsartan'ın mortalite ve kalp yetersizliği hospitalizasyon ötesi klinik yararları nelerdir?
}

\author{
D Dr. Burcu Demirkan
}

Ankara Şehir Hastanesi, Kardiyoloji Kliniği, Ankara

Kalp yetersizliği (KY) patofizyolojisinde nörohormonal sistemler hastalığın gelişimi ve ilerlemesinden esas sorumlu mekanizmalar olması sebebiyle, bu sistemlerin modülasyonunu sağlayan beta-blokerler, anjiyotensin dönüştürücü enzim inhibitörleri (ACEI), anjiyotensin reseptör blokerleri (ARB) ve mineralokortikoid reseptör antagonistleri (MRA) düşük ejeksiyon fraksiyonlu kalp yetersizliğinin (DEF-KY) tedavisinde morbidite ve mortaliteyi azaltmak amaciyla yıllardır kullanılmaktadır. ${ }^{[1,2]}$

Uzun süre bu tedavilere ek başka etkili bir farmakoterapi kullanıma sunulmamıştı. En son geliştirilen, çift bileşenli bir molekül olan sakubitril/valsartan (S/V), anjiyotensin reseptör blokajına ek olarak neprilisin inhibisyonu ile tedavide natriüretik peptidlerin (NP) etkisini arttırmamızı ve bu peptidlerin faydalı etkilerinden tedavide yararlanmamızı sağladı. ${ }^{[3]}$

Sakubitril/valsartan, 2015 yılında, Avrupa İlaç Ajansı (EMA) tarafından semptomatik, DEF-KY tedavisinde kullanılmak üzere "Prospective Comparison of ARNI with ACEI to Determine Impact in Global Mortality and Morbidity in Heart Failure" (PARADIGM-HF) çalışmasının sonuçları neticesinde onayland1.$^{[4,5]}$

Prospektif, çift-kör, randomize bir çalışma olan PARADIGM-HF'de; DEF-KY bulunan hastalarda, S/V 2x200 mg/gün ve enalapril 2x10 mg/gün tedavileri karşılaştırıldı. Çalışma 27 aylık bir takip sonunda gruplar arasında anlamlı fark gözlenmesi sebebiyle erken sonlandırıldı. Çalışmada, birincil birleşik sonlanım noktası olarak belirlenen kardioyovasküler (KVS) ölüm veya KY kötüleşmesine bağlı hastaneye yatışı, S/V tedavisinin enalaprile göre, \%20 oranında daha fazla azaltarak daha üstün olduğu gösterildi. Bunun yanı sıra birincil sonlanım noktasını oluşturan bileşenler ayrı ayrı değerlendirildiğinde de; $\mathrm{S} / \mathrm{V}$ tedavisinin, birbirinden ayrı olarak; KVS nedenli ölümlerde $\% 20$ oranında azalma ve KY nedenli hastaneye yatışta \%21 oranında daha fazla azalma sağladığı tespit edildi (Tablo 1). Yirmi yedi aylık takipte, bir KVS nedenli ölüm veya KY nedenli hastaneye yatışı azaltmak için tedavi gerektiren sayının (NNT) 21, bir kardiyak ölümü engellemek için NNT 32 ve bir KY kötüleşmesine bağlı olarak yatış1 engellemek için NNT 36 olarak hesapland.$_{.}{ }^{[4]}$

Çalışmanın ikincil sonlanım noktası olarak belirlenen tüm nedenli ölümlerde, $\mathrm{S} / \mathrm{V}$ ile enalapril grubuna kıyasla \%16 oranında azalma sağlanırken, S/V alan hastaların semptomlarında ve fiziksel kısıtlılıkta Kansas Şehri Kardiyomiyopati Anketi ile 8. ay skor değerlerinin daha iyi olduğu görüldü. Diğer belirlenen ikincil sonlanım noktaları olan yeni atriyal fibrilasyon (AF) gelişimi ve renal fonksiyonda kötüleşmede her iki tedavi arasında farklılık izlenmedi (Tablo 1). ${ }^{[4]}$

Kalp yetersizliği sadece ölüm riskini arttıran bir durum değildir. Ölüm riski yanı sıra, tekrarlayan ölümcül olmayan semptom kötüleşmesi, fonksiyonel kapasite ve yaşam kalitesinin ilerleyici şekilde bozulması KY'nin yükünü oluşturan önemli problemlerdir. Ölümcül olmayan kötüleşmeler, hastalarda kullanılan oral ilaçların arttırılmasını, hastaneye yatış veya yoğun bakıma kabul gerektiren acil tedavi ihtiyacını doğurabilmektedir. ${ }^{[6]} \mathrm{Bu}$ yüzden tedavide amaç sadece sağ kalımı uzatmak değil, aynı zamanda hastaların klinik durumunu korumak, ölümcül olmayan kötüleşmeler ve beraberinde getirdiği sonuçları azaltmayı da içermektedir. PARADIGM-HF çalışmasında mortalite açısından üstünlüğü gösterilen S/V tedavisinin, çalışmanın sonradan yapılan diğer analizlerinde, sağlık hizmet kaynaklarının daha az kullanımı ile ilişkili olduğuna dair veriler de elde edilmiştir (Tablo 2)..$^{[7,8]}$

Enalapril alan hastalar ile karşılaştırıldı ğında, S/V ile tedavi edilen hastalarda mevcut tedaviye yeni ilaç eklenmesi, intravenöz (IV) ilaç tedavisi veya diüretik doz artış ihtiyacı daha az gerçekleşmektedir (RO: 0.84; \%95 GA, 0.74-0.94; $\mathrm{p}=0.003){ }^{[7]}$ 
Tablo 1. PARADIGM-HF çalışmasındaki birincil ve ikincil sonlanım noktaları

\begin{tabular}{|c|c|c|c|c|}
\hline Sonlanım & $S / V(n=4187)$ & Enalapril $(\mathrm{n}=4212)$ & Risk oranı* (\%95 GA) & $p$ \\
\hline Birincil birleşik sonlanım - n (\%) & $914(21.8)$ & $1117(26.5)$ & $0.80(0.73-0.87)$ & $<0.001$ \\
\hline \multicolumn{5}{|l|}{ (KV nedenli ölüm veya KY'nin } \\
\hline \multicolumn{5}{|l|}{ kötüleşmesi nedeniyle ilk hastaneye yatış) } \\
\hline Kardiyovasküler nedenli ölüm & $558(13.3)$ & $693(16.5)$ & $0.80(0.71-0.89)$ & $<0.001$ \\
\hline KY nedenli ilk hastaneye yatış & $537(12.8)$ & $693(16.5)$ & $0.79(0.71-0.89)$ & $<0.001$ \\
\hline \multicolumn{5}{|l|}{ İkincil sonlanımlar - n (\%) } \\
\hline Herhangi bir nedenle ölüm & $711(17.0)$ & $835(19.8)$ & $0.84(0.76-0.90)$ & $<0.001$ \\
\hline \multicolumn{5}{|l|}{ 8. ayda KCCQ klinik özet skorunda ${ }^{\dagger}$} \\
\hline değişim, ortalama $\pm S D$ & $-2.99 \pm 0.36$ & $-4.63 \pm 0.36$ & $1.64(0.63-2.65)$ & 0.001 \\
\hline Yeni başlangıçlı atriyal fibrilasyonף & $84(3.1)$ & $83(3.1)$ & $0.97(0.72-1.31)$ & 0.83 \\
\hline Renal fonksiyonda kötüleşme ${ }^{\S}$ & $94(2.2)$ & $108(2.6)$ & $0.86(0.65-1.13)$ & 0.28 \\
\hline
\end{tabular}

*: Cox orantısal risk modeli kullanılarak hesaplanmıştı; †: KCCQ skorları 0 ila 100 arasında değişmektedir. Yüksek skorlar, KY ile ilişkili daha az semptom ve daha az fiziksel kısıtılık olduğunu göstermektedir; : Randomizasyonda atriyal fibrilasyonu olmayan, LCZ696 grubundaki 2670 hasta ve enalapril grubundaki 2638 hasta değerlendirilmiştir; §: Şöyle tanımlanır: (a) Randomizasyondakine göre eGFR'de $2 \% 50$ düşüş; (b) eGFR'de randomizasyona göre >30 mL/ dak/1.73 $\mathrm{m}^{2}$ düşüş veya $<60 \mathrm{~mL} / \mathrm{dak} / 1.73 \mathrm{~m}^{2}$ değerine düşüş veya (c) son dönem böbrek hastalı̆̆ gelişmesi.

Sakubitril/valsartan kullanan hastaların KY kötüleşmesi nedeniyle acil servise başvurularının daha az olduğu görülmüştür (RO: 0.66; \%95 GA, 0.52-0.85; $\mathrm{p}=0.001$ ). Tüm tekrarlayan KY nedenli acil başvuruları göz önüne alındığında $\mathrm{S} / \mathrm{V}$ tedavisi, enalaprile göre bu başvuruları \%30 oranında azaltmaktadır. ${ }^{[7]}$

Sakubitril/valsartan tedavisi alan hastalarda; KY nedenli, kardiyovasküler nedenli veya herhangi bir nedenli ilk hastaneye yatış, enalapril alan hastalara göre daha az gerçekleşmiştir. Hastaneye yatış riskindeki azalma her iki ilaç arasında oldukça erken bir sürede, randomizasyonu takip eden ilk 30 günde anlamlı olarak farklanmaktadır (RO: 0.60; \%95 GA, 0.38-0.94; $\mathrm{p}=0.027)$. Sakubitril/ valsartan tedavisi ile hastaların KY nedeniyle hastaneye birden fazla yatma oranı da enalapril tedavisi alanlara göre $\% 29$ daha az olarak görülmüştür ( $\mathrm{p}=0.001)$. Tüm hastaneye yatışlar göz önüne alındığında (bir kez ve tüm tekrarlayan yatışlar), S/V tedavisi ile herhangi bir nedenle, kardiyovasküler nedenle ve KY nedeniyle sırasiyla \%15.6, \%16 ve $\% 23$ oranında daha az hastaneye yatış mevcuttur. ${ }^{[7]}$

Hastaneye kabulü yapılan vakalarda ise, S/V tedavisi almakta olan hastaların, enalapril alanlara göre, yoğun bakım ihtiyac1 $\% 18$ ( $\mathrm{p}=0.005)$, IV pozitif inotrop ihtiyac1 \%31 $(\mathrm{p}<0.001)$ ve kardiyak transplant veya mekanik destek cihaz ihtiyacı \%22 oranında daha az olmuştur $(\mathrm{p}=0.07) \cdot{ }^{[7]}$

Çalışmadaki tüm popülasyonda, KY nedenli ile hastaneye yatan her 5 hastaya karşıllk, 1 hastada taburculuk sonrası ilk 30 gün içinde tekrar hastaneye yatış gerçekleşmiştir. Sakubitril/valsartan tedavisi bu tekrarlayan ilk 30 günlük tüm nedenli hastaneye yatışlarını da \%26 oranında (\%17.8'e karşılık \%21, RO: 0.74; \%95 GA: 0.56-0.97; $\mathrm{p}=0.031$ ) ve KY nedeniyle olanları ise \%38 oranında daha fazla azaltmaktadır (\%9.7'ye karş1lık \%13.4; RO: 0.62; \%95 GA: 0.45$0.87, \mathrm{p}=0.006$ ). Taburculuk sonrası bu 30 günlük süre 60 güne uzatılarak değerlendirme yapıldığında da, $\mathrm{S} / \mathrm{V}$ tedavisinin üstün olan etkisi sürmektedir. Kalp yetersizliği hastalarında taburculuk sonrası ilk 30 gün hassas bir periyod olup, erken dönem tekrarlayan hastane yatışları hem artmış mortalite, hem de artan tedavi maliyetleri ile ilişkilidir. KY nedenli yatış sonrası erken dönem tekrarlayan yatışları S/V azaltarak hastaların sonucunu iyileştirmektedir. ${ }^{[8]}$

Enalapril alan grupta ölüm nedeniyle daha fazla sayıda ve kötü durumdaki hasta kaybedilmiş olmasına rağmen, yaşayan hastaların daha büyük bir kısmında fonksiyonel kapasiteleri S/V kullanan hastalara göre daha kötüydü. Hastaların takipte 4., 8. ve 12. aylarda KCCQ ile yapılan değerlendirmelerinde, S/V alan hastalar daha iyi yaşam kalitesi ile uyumlu skorlara sahipti (Tablo 2)..$^{7]}$

Sakubitril/valsartan tedavisi alan hastalarda kliniğe yansiyan bu olumlu sonuçlar laboratuvar verileriyle de uyumludur. Enalapril alanlara göre, S/V alan hastalarda; üriner cGMP ve plazma BNP daha yüksek seyrederken (neprilisin inhibisyonuna bağlı olarak), azalmış miyokart duvar gerilimini yansitacak şekilde, plazma NT-proBNP ve azalmış miyokardiyal hasarı yansıtacak şekilde, troponin düzeyleri daha düşük seyretmiş- 
Tablo 2. Kalp yetersizliğinin ölümcül olmayan kötüleşme ölçütlerinin enalapril ve $\mathbf{S} / \mathrm{V}$ tedavisi ile karşılaştırılması ${ }^{[7]}$

\begin{tabular}{|c|c|c|c|c|}
\hline & Enalapril $(n=4212)$ & $S / V(n=4187)$ & Risk oranı (\%95 GA) & $\mathrm{p}$ \\
\hline \multicolumn{5}{|l|}{ Ayaktan hastalarda kötüleşen KY'e bağlı } \\
\hline tedavi artışı, n (\%) & $604(14.3)$ & $520(12.4)$ & $0.84(0.74-0.94)$ & 0.003 \\
\hline \multicolumn{5}{|l|}{ NYHA sınıfında kötüleşme ( $\geq 1)$} \\
\hline Yaşayan hastalarda 4. ayda, n (\%) & $218(5.5)$ & $186(4.7)$ & & 0.113 \\
\hline Yaşayan hastalarda 8. ayda, n (\%) & $266(7.0)$ & $205(5.4)$ & & 0.004 \\
\hline Yaşayan hastalarda 12. ayda, n (\%) & $271(7.4)$ & $225(6.1)$ & & 0.023 \\
\hline \multicolumn{5}{|l|}{$\mathrm{KCCQ}$ total semptom skorunda } \\
\hline \multicolumn{5}{|l|}{ kötüleşme olan hastalar ( $\geq 5$ puan) } \\
\hline Yaşayan hastalarda 4. ayda & $1012(28.3)$ & $899(25.1)$ & & 0.002 \\
\hline Yaşayan hastalarda 8. ayda & $1087(31.8)$ & $974(28.2)$ & & 0.001 \\
\hline Yaşayan hastalarda 12. ayda & $1029(31.5)$ & $964(29.0)$ & & 0.03 \\
\hline KY nedeniyle acil servise başvuru yapan hastalar, $\mathrm{n}(\%)$ & $150(3.6)$ & $102(2.4)$ & $0.66(0.52-0.85)$ & 0.001 \\
\hline KY nedeniyle toplam acile başvuru sayısı & 208 & 151 & $0.70(0.52-0.94)$ & 0.017 \\
\hline KY nedeniyle hastaneye yatan hastalar, $n(\%)$ & $658(15.6)$ & $537(12.8)$ & $0.79(0.71-0.89)$ & $<0.001$ \\
\hline KY nedeniyle toplam hastaneye yatış sayısı & 1079 & 851 & $0.77(0.67-0.89)$ & $<0.001$ \\
\hline Hastaneye yatış başına hastanede kalış gün sayısı & $9.7 \pm 9.5$ & $10.8 \pm 17.5$ & & 0.86 \\
\hline Yoğun bakım ihtiyacı olan hasta sayısı & 623 & 549 & $0.87(0.78-0.98)$ & 0.019 \\
\hline Yoğun bakımda toplam kalış sayısı & 879 & 768 & $0.82(0.72-0.94)$ & 0.005 \\
\hline IV pozitif inotrop alan hastalar, $\mathrm{n}(\%)$ & $229(5.4)$ & $161(3.9)$ & $0.69(0.57-0.85)$ & $<0.001$ \\
\hline KRT, VAD veya kalp nakli intiyacı olan hastalar, n (\%) & $119(2.8)$ & $94(2.3)$ & $0.78(0.60-1.02)$ & 0.07 \\
\hline Kardiyovasküler nedenli hastaneye yatan hastalar, n (\%) & $1344(31.9)$ & $1210(28.9)$ & $0.88(0.81-0.95)$ & $<0.001$ \\
\hline Kardiyovasküler nedenli toplam hastaneye yatış sayısı & 2537 & 2216 & $0.84(0.76-0.92)$ & $<0.001$ \\
\hline \multicolumn{5}{|l|}{ Herhangi bir nedenle hastaneye } \\
\hline yatış yapılan hastalar, n (\%) & $1827(43.4)$ & $1660(39.7)$ & $0.88(0.82-0.94)$ & $<0.001$ \\
\hline Herhangi bir nedenle hastaneye toplam yatış sayısı & 4053 & 3564 & $0.84(0.78-0.92)$ & $<0.001$ \\
\hline
\end{tabular}

IV: Intravenöz; KRT: Kardiyak resenkronizasyon tedavisi; KY: Kalp yetersizliği; NYHA: New York Kalp Cemiyeti; VAD: Ventriküler destek cihazı.

tir. Biyobelirteçlerdeki bu farklılık ilk 4 hafta içerisinde belirmekte ve çalışma boyunca sürmektedir. ${ }^{[7]}$

Özetle; elimizdeki kanıtlara göre, S/V tedavisi kalp yetersizliğinde sadece mortalitenin düşürülmesinde değil, semptom kötüleşmesi ve ölümcül olmayan klinik bozulmaları azaltarak hastaların yaşam kalitesini iyileştirmede de elimizi güçlendiren bir tedavi olarak karşımıza çıkmaktadır.

\section{Kaynaklar}

1. Ponikowski P, Voors AA, Anker SD, Bueno H, Cleland JGF, Coats AJS, et al. 2016 ESC Guidelines for the diagnosis and treatment of acute and chronic heart failure: The Task Force for the diagnosis and treatment of acute and chronic heart failure of the European Society of Cardiology (ESC)Developed with the special contribution of the Heart Failure Association (HFA) of the ESC. Eur Heart J 2016;37:2129-200.

2. Yancy CW, Jessup M, Bozkurt B, Butler J, Casey DE Jr, Drazner MH, et al. $2013 \mathrm{ACCF} / \mathrm{AHA}$ guideline for the management of heart failure: a report of the American College of Cardiology Foundation/Ameri- can Heart Association Task Force on practice guidelines. Circulation 2013;128:e240-327.

3. Braunwald E. The path to an angiotensin receptor antagonist-neprilysin inhibitor in the treatment of heart failure. J Am Coll Cardiol 2015;65:1029-41.

4. McMurray JJ, Packer M, Desai AS, Gong J, Lefkowitz MP, Rizkala AR, et al. Angiotensin-neprilysin inhibition versus enalapril in heart failure. N Engl J Med. 2014;371:993-1004.

5. European Medicines Agengy (EMA). Entresto. Summary of product characteristics. Available at: https://www.ema.europa.eu/en/medicines/ human/EPAR/entresto\#product-information-section. Accessed Jul 14, 2020.

6. McMurray JJ, Packer M, Desai AS, Gong J, Lefkowitz MP, Rizkala $\mathrm{AR}$, et al. Angiotensin-neprilysin inhibition versus enalapril in heart failure. N Engl J Med 2014;371:993-1004.

7. Packer M, McMurray JJ, Desai AS, Gong J, Lefkowitz MP, Rizkala AR, et al. Angiotensin receptor neprilysin inhibition compared with enalapril on the risk of clinical progression in surviving patients with heart failure. Circulation 2015;131:54-61.

8. Desai AS, Claggett BL, Packer M, Zile MR, Rouleau JL, Swedberg $\mathrm{K}$, et al. Influence of Sacubitril/Valsartan (LCZ696) on 30-Day Readmission After Heart Failure Hospitalization. J Am Coll Cardiol 2016;68:241-8. 